\title{
The Effect of Sheep Feces Compost with Different Fertilization Doses and Intervals on the Productivity of Mixed Pastures (Clitoria ternatea and Brachiaria ruziziensis)
}

\author{
D.A.Y.Purba ${ }^{1}$, N.Ginting ${ }^{1 *}$ Yunilas $^{1}$, and Alwiyah ${ }^{2}$ \\ ${ }^{1}$ Animal Production Program Study, Faculty of Agriculture, University of North Sumatra, Padang Bulan, \\ Medan 20155, Indonesias \\ ${ }^{2}$ Indonesia Goat Research Station, SeiPutih, Indonesia \\ Correspondent author: nurzainahginting@gmail.com
}

\begin{abstract}
Mix pasture contains more complete nutrition for animal feed. This study aims to determine the effect of giving sheep feces compost with different fertilization doses and intervals on the productivity of mixed pastures (Clitoria ternatea and Brachiaria ruziziensis). This research was conducted in Kotangan Village, Kec. Galang, Kab. Deli Serdang North Sumatra from September to November 2020. The experimental design was used a split-plot design with two treatment factors and three replications. Factor I is the main plot, namely the fertilization interval: $\mathrm{N} 1=$ once every four weeks and $\mathrm{N} 2=$ once every two weeks. Factor II as a subplot which were doses of compost : $\mathrm{P} 0=$ control (without compost), $\mathrm{P} 1=$ compost 1 $\mathrm{kg} / \mathrm{plot}(10 \mathrm{t} / \mathrm{h}), \mathrm{P} 2=$ compost $2 \mathrm{~kg} / \mathrm{plot}(20 \mathrm{t} / \mathrm{h})$ and $\mathrm{P} 3=$ compost $3 \mathrm{~kg} / \mathrm{plot}(30 \mathrm{t} / \mathrm{h})$. The variables observed were plant height, number of leaves, number of tillers, number of branches, fresh production, dry matter, crude protein, and crude fiber. The results showed that sheep feces compost doses and different time intervals for fertilization had a significant effect $(\mathrm{P}<0,05)$ on the number of leaves and tillers of Brachiaria ruziziensis, crude protein, and coarse fiber of mixed pasture. There was no significant effect $(P>0,05)$ on plant height, the number of leaves and number of branches of Clitoria ternatea, the height of Brachiaria ruziziensisas, and fresh and dry mixed pasture production. The appropriate fertilization interval was once every two weeks, and the best fertilizer dose was $3 \mathrm{~kg} / \mathrm{plot}(30 \mathrm{t} / \mathrm{h})$.
\end{abstract}

Keywords : brachiaria ruziziensis, clitoria ternatea, doses, feces compost, fertilization interval

\section{Introduction}

Forage fodder is an important thing that can affect livestock productivity, for that forage (feed) must be considered for its availability. Good forage can be seen from the quality or content of nutrients. Besides that, the amount must be sufficient, and its availability is continuous throughout the year [1]. The need for ruminants for forage is $10 \%$ of their body weight. The lack of forage availability for ruminants can interfere with their productivity. Forage consists of grasses and legumes that require adequate nutrition to meet their needs to increase their productivity. According to [2], legumes contain more protein than grass, while grass contains more carbohydrates than legumes. Fertilization aims to meet the nutrients needed by plants to grow optimally and produce good quality production [3]. 
In facing the current era of globalization, many efforts were needed to reduce pollution to the environment. Sheep feces is livestock waste that contains methane gas or $\mathrm{CH} 4$, which can damage the environment if not treated properly. This gas is not only a greenhouse gas (Green House Gas) but also causes unpleasant odors and is detrimental to human health. Although it harms the environment, sheep feces also have the potential to be used as organic fertilizer that can improve soil structure and quality with proper processing. According to [4], manure contains not only macro elements such as nitrogen $(\mathrm{N})$, phosphate $(\mathrm{P})$, and potassium $(\mathrm{K})$ but also contains microelements such as calcium $(\mathrm{Ca})$, magnesium $(\mathrm{Mg})$, and manganese. $(\mathrm{Mn})$ plants and plays a role in maintaining the balance of nutrients in the soil because manure has an effect for a long time and is a food store for plants.

Processing of farm waste into the fertilizer can be done by fermentation or composting. The addition of liquid organic fertilizer from fruit and fish intestines as a bio activator can add nutrients to the compost and accelerate the composting process. The use of farm waste as an organic fertilizer has been studied before was known to increase several types of forage. Based on these results, the researchers were interested in examining compost from sheep feces processed, which used bio activator from fruit waste and fish intestines on the productivity of mixed pasta between Clitoria ternate and Brachiaria ruziziensis.

\section{Materials and Methods}

This research was carried out in the village of Kampung Kotangan, Kec. Galang, Kab. Deli Serdang North Sumatra and was conducted from September to November 2020. The materials used were Brachiaria Ruziziensisand Clitoria Ternatea, sheep feces, organic bio activator, nonchlorine water, and molasses. There were 24 plots of 1 x $1 \mathrm{~m}$, with 9 plants per plot (4 Brachiaria Ruziziensis and 5 Clitoria Ternatea).

\subsection{Research Methods}

The experimental design was used a split-plot design with two treatment factors and three replications.

The first factor is the main plot, namely the fertilization interval :

$\mathrm{N} 1$ = once every four weeks

$\mathrm{N} 2$ = once every two weeks

The second factor as a sub plot is the provision of compost fertilizer :

$\mathrm{P}_{1}=$ compost $1 \mathrm{~kg} / \mathrm{plot}(10 \mathrm{t} / \mathrm{h})$

$\mathrm{P}_{2}=$ compost $2 \mathrm{~kg} / \mathrm{plot}(20 \mathrm{t} / \mathrm{h})$

$\mathrm{P}_{3}=$ compost $3 \mathrm{~kg} / \mathrm{plot}(30 \mathrm{t} / \mathrm{h})$ 


\subsection{Research Parameters}

Plant height

Plant height is obtained by measuring plant Clitoria ternatea and Brachiaria ruziziensisstart from the ground level up to the highest end of the leaf/shoot.

Number of Leaves

Count the number of leaves of the Clitoria ternatea, and Brachiaria ruziziensis grows every two weeks until harvest.

Number of Branches

Counted the number of branches of the Clitoria ternatea that grows every two weeks until harvest.

Number of Tillers

Counted every Brachiaria ruziziensis tiller that grows every two weeks until harvest.

Fresh Production

Fresh production is obtained from weighing the yield of each treatment in new form with a plant age of 2 months.

Dry Material Production

Production of dry material obtained from a sample of the material production of fresh weighing 50 grams was put into an oven at a temperature of $60^{\circ} \mathrm{C}$ for $24 \mathrm{~h}$ and then weighed to obtain the dry weight.

\section{Crude Fiber and Crude Protein}

Analysis of the nutritional content of crude fiber and crude protein was carried out using a proximate analysis of the harvested results.

Crude Fiber (CF)

$$
\text { Crude fiber }(\%)=\frac{\text { sample weight }- \text { ash weight }}{\text { sediment weight on filter paper }} \times 100
$$


$\mathrm{CP}(\%)=\frac{(\mathrm{V} 1 \mathrm{HCl} \text { titrant example }-\mathrm{V} 2 \mathrm{HCl} \text { titrant blank }) \times \mathrm{N} \mathrm{HCl} \times 0.014 \times 6.25 \times \text { Fpcrude }}{\text { weight sample }}$

\subsection{Research Implementation}

The research was carried out with several procedures, namely making liquid organic fertilizer as a substitute for fermentor for 21 days, making compost from sheep feces for 28 days, preparing the land, and planting media with a plot size of $1 \times 1 \mathrm{~m}$ and a height of $15 \mathrm{~cm}$ as many as 24 plots, making a fence $80 \mathrm{~cm}$ high, sowing seeds for two weeks, planting $30 \times 30 \mathrm{~cm}$ spacing, maintaining and harvesting at 60 days of planting.

\subsection{Data Analysis}

The data obtained were analyzed using analysis of variance (variance). If the treatment was significantly different $(\mathrm{F} \geq 0,05)$ or very significant $(\mathrm{F} \geq 0.01)$, it was further tested using the Duncan test.

\section{Results And Discussion}

\subsection{Height of Clitoria ternatea $(\mathrm{cm})$}

Table 1. Plant height $(\mathrm{cm})$ Clitoria ternatea by giving sheep feces compost with different fertilization doses and intervals

\begin{tabular}{cccccc}
\hline Fertilization & \multicolumn{4}{c}{ Fertilizer Doses } & \multirow{2}{*}{ Average } \\
\cline { 2 - 5 } Interval & $\mathrm{P} 0$ & $\mathrm{P} 1$ & $\mathrm{P} 2$ & $\mathrm{P} 3$ & \\
\hline $\mathrm{N} 1$ & 74.70 & 84.27 & 96.50 & 106.73 & $90.55^{\mathrm{tn}}$ \\
$\mathrm{N} 2$ & 75.25 & $84.47^{\mathrm{n}}$ & $94.13^{\mathrm{n}}$ & 105.87 & $89.93^{\mathrm{tn}}$ \\
\hline Average & $74.97^{\mathrm{a}}$ & $84.37^{\mathrm{b}}$ & $95.32^{\mathrm{c}}$ & $106.30^{\mathrm{d}}$ & \\
\hline
\end{tabular}

Note: Different superscripts on the same row or column show significant differences $(\mathrm{P}<0.05)$, tn $=$ not significant

The diversity analysis results showed that the fertilization time interval did not have a significant effect $(\mathrm{P}>0.05)$ on the height of the Clitoria ternatea. In contrast, the difference in the doses of sheep fecal compost had a significant effect $(\mathrm{P}<0.05)$ on the height of the Clitoria ternatea. There was no interaction between the dose and interval of fertilization on the height of the Clitoria ternatea. This was because the Clitoria ternatea plant is a type of vine with many branches in its leaf axils so that its growth is not only focused on plant height but also on increasing the number of branches, the length of each branch, and leaf growth. This was following the statement [2], who stated that the Clitoria ternatea generally is a shrub that grows vines. In the axils of the leaves, there is a line-shaped supporting leaf.

"Table 1" it can be seen that the highest average value for the plant height of Clitoria ternatea with different doses of sheep feces compost was found in the P3 treatment (compost dose $3 \mathrm{~kg} / \mathrm{plot}$ 
or $30 \mathrm{t} / \mathrm{h}$ ), which was $106.30 \mathrm{~cm}$, the higher the dose. This was because the roots of the Clitoria ternateaplant have root fibers that can make maximum use of the nutrients contained in the applied compost even though the fertilization time is different so that the statistical data test did not show significantly different results between the two-week fertilization time interval and once every four weeks. This was under the statement [5] who stated that the root consists of a taproot with several branches and many lateral roots. It has thick horizontal roots, which can grow to more than $2 \mathrm{~m}$.

\subsection{Height of Brachiaria ruziziensis $(\mathrm{cm})$}

Table 2. Plant height $(\mathrm{cm})$ of Brachiaria ruziziensis by giving sheep feces compost with different fertilization doses and intervals

\begin{tabular}{cccccc}
\hline Fertilization & \multicolumn{4}{c}{ Fertilizer Doses } & \multirow{2}{*}{ Average } \\
\cline { 2 - 5 } Interval & $\mathrm{P} 0$ & $\mathrm{P} 1$ & $\mathrm{P} 2$ & $\mathrm{P} 3$ & \\
\hline $\mathrm{N} 1$ & 68.50 & 83.75 & 83.33 & 77.00 & $78.15^{\mathrm{tn}}$ \\
N2 & 72.67 & 80.42 & 82.67 & 84.17 & $79.98^{\text {tn }}$ \\
\hline Average & $70.58^{\mathrm{a}}$ & $82.08^{\mathrm{b}}$ & $83.00^{\mathrm{b}}$ & $80.58^{\mathrm{b}}$ & \\
\hline
\end{tabular}

Note: Different superscripts on the same row or column show significant differences $(\mathrm{P}<0.05)$, tn $=$ not significant

The results of the diversity analysis showed that the fertilization time interval did not have a significant effect $(\mathrm{P}>0.05)$ on the height of Brachiaria ruziziensi. In contrast, the difference in the dose of sheep fecal compost had a significant effect $(\mathrm{P}<0.05)$ on the height of Brachiaria ruziziensiand. There was no interaction between the doses and the interval of fertilization on the height of Brachiaria ruziziensi. This was because the Brachiaria ruziziensis plant is a plant that can grow stolons so that when the stem touches the ground, it will grow new roots. This was by the statement [6] who stated that Brachiaria ruziziensishave stolons' morphological characteristics were able to develop quickly to form dense expanses to cover the soil and prevent erosion

"Table 2" it can be seen that even though the time for fertilizing the plants was different, the amount of fertilizer given was the same between N1 and N2 so that there was no real difference between plant height growth at N1 and N2. It also showed that sheep fecal compost contains nutrients easily absorbed by Brachiaria ruziziensisplants. Many nutrients or often given did not guarantee that these nutrients can be utilized optimally by plants. This was following the statement [7] who stated that large amounts of nutrients were not assured that roots could be absorbed. The highest average value for Brachiaria ruziziensis plant height with different doses of sheep feces compost was found in P2 treatment (compost dose $2 \mathrm{~kg} / \mathrm{plot}$ or $20 \mathrm{t} / \mathrm{h}$ ), which was $83,00 \mathrm{~cm}$. [8] mentioned that fertilizer application regularly and periodically and with the correct dose greatly supports plant growth. 


\subsection{Number of Leaves of Clitoria ternatea}

Table 3. Number of Clitoria ternatealeaves by giving sheep feces compost with different fertilization doses and intervals

\begin{tabular}{cccccc}
\hline Fertilization & \multicolumn{4}{c}{ Fertilizer Doses } & \multirow{2}{*}{ Average } \\
\cline { 2 - 5 } Interval & $\mathrm{P} 0$ & $\mathrm{P} 1$ & $\mathrm{P} 2$ & $\mathrm{P} 3$ & \\
\hline $\mathrm{N} 1$ & 124.67 & 165.00 & 180.67 & 207.73 & $169.52^{\mathrm{tn}}$ \\
N2 & 126.13 & 160.67 & 178.87 & 221.33 & $171.75^{\mathrm{tn}}$ \\
\hline Average & $125.40^{\mathrm{a}}$ & $162.83^{\mathrm{b}}$ & $179.77^{\mathrm{c}}$ & $214.53^{\mathrm{d}}$ & \\
\hline
\end{tabular}

Note: Different superscripts on the same row or column show significant differences $(\mathrm{P}<0.05)$ tn $=$ not significant

The results of the diversity analysis showed that the time interval for fertilization did not have a significant effect $(\mathrm{P}>0.05)$ on the number of leaves of the Clitoria ternateaplant. At the same time, the different doses of sheep feces compost gave significant results $(\mathrm{P}<0.05)$ on the number of leaves of Clitoria ternatea, and there was no interaction between the dose and interval of fertilization on the number of leaves of the Clitoria ternatea plant. This was because a sound root system will maximize the absorption of nutrients, and forming plant cells will run well. This was consistent with the statement [9] who stated that root formation was influenced by the supply of nutrients in the growing media. It required macronutrient components in adequate concentrations and was also influenced by the porosity of the media. The better the drainage and aeration, the better the root development so that the formation of plant cells will be better.

"Table 3" it can be seen that the fertilization interval was intended to minimize the possibility of leaching of nutrients due to rain and water with no significant difference between the N1 and N2 fertilization time intervals. It is indicating that the nutrients from sheep fecal compost are given did not experience nutrient leaching. Also, its availability in the soil was maintained and can be used for vegetative growth, including the expansion of plant leaves. This was following the statement [10], who stated that if the leaching of elements was considerable, the loss of nutrients was more significant than the uptake of nutrients by plants. [11] mentioned that the nutrient that affects the growth and development of leaves is Nitrogen $(\mathrm{N})$. Such treatment levels of nitrogen (N) could obtain the highest growth rate the most optimal number of leaves.

\subsection{Number of leaves of Brachiaria ruziziensis}

Table 4. The number of leaves of Brachiaria ruziziensis by giving sheep feces compost with different fertilization doses and intervals

\begin{tabular}{cccccc}
\hline Fertilization & \multicolumn{4}{c}{ Fertilizer Doses } & Average \\
\cline { 2 - 5 } Interval & $\mathrm{P} 0$ & $\mathrm{P} 1$ & $\mathrm{P} 2$ & $\mathrm{P} 3$ & \\
\hline $\mathrm{N} 1$ & 117.25 & 153.42 & 203.33 & 154.33 & $157.08^{\mathrm{a}}$ \\
N2 & 119.00 & 165.42 & 192.00 & 261.42 & $184.46^{\mathrm{b}}$ \\
\hline Average & $118.13^{\mathrm{a}}$ & $159.42^{\mathrm{b}}$ & $197.67^{\mathrm{c}}$ & $207.88^{\mathrm{c}}$ & \\
\hline
\end{tabular}

Note: Different superscripts in the same row or column show significant differences $(\mathrm{P}<0.05)$

The results of the diversity analysis showed that the time interval for fertilization and the administration of different sheep feces compost had a significant effect $(\mathrm{P}<0.05)$ on the number 
of leaves of the Brachiaria ruziziensisplant, and there was an interaction between the dose and interval of fertilization on the number of leaves of the Brachiaria ruziziensis. This was because the application of time and the correct doses of fertilizers can maintain the availability of nutrients in the soil to continue to be used by plants for their growth and development. This was consistent with the statement [12] who stated that the merits of plant growth and development or increased and reduced crop production given the increase or reduction is influenced by the nutrients provided.

"Table 4" it can be seen that the highest average percentage of crude fiber content is found in the N2 treatment (once every two weeks), which was 184.46 strands. N1 treatment (once every four weeks), the average number of leaves of the Brachiaria ruziziensis plant was lower, namely 157.08. This was because the fertilization time of every two weeks results in the availability of nutrients in the soil faster than fertilizing once every four weeks. These nutrients can be immediately used by ruzi plants to form their leaves. Because during the vegetative period, plants need nutrients so that their growth can occur optimally. This was by the statement[13] who stated that each nutrient has its role in supporting plant metabolic processes. Nitrogen was a macronutrient that was an integral part of chlorophyll, so it was responsible for photosynthesis.

\subsection{Number of Branches of Clitoria ternatea}

Table 5. The number of branches of Clitoria ternateaby giving sheep feces compost with different fertilization doses and intervals

\begin{tabular}{|c|c|c|c|c|c|}
\hline \multirow{2}{*}{$\begin{array}{c}\text { Fertilization } \\
\text { Interval }\end{array}$} & \multicolumn{4}{|c|}{ Fertilizer Doses } & \multirow[t]{2}{*}{ Average } \\
\hline & P0 & P1 & P2 & P3 & \\
\hline N1 & 18.07 & 21.67 & 23.20 & 26.00 & $22.23^{\mathrm{tn}}$ \\
\hline $\mathrm{N} 2$ & 17.93 & 21.40 & 23.53 & 26.87 & $22.43^{\mathrm{tn}}$ \\
\hline Average & $18.00^{\mathrm{a}}$ & $21.53^{\mathrm{b}}$ & $23.37^{\mathrm{c}}$ & $26.43^{d}$ & \\
\hline
\end{tabular}

The analysis of variance showed that the time interval for fertilization did not have a significant effect $(\mathrm{P}>0.05)$ on the number of branches of the Clitoria ternatea plant. At the same time, the different doses of sheep feces compost gave significant results $(\mathrm{P}<0.05)$ on the number of branches of the Clitoria ternatea. There was no interaction between the dose and interval of fertilization on the number of branches of the Clitoria ternateaplant. Besides being influenced by the availability of $\mathrm{P}$ nutrients, the formation of plant branches is also influenced by other factors, namely the intensity of sunlight. This was per the statement [14], who stated that intensity light would affect plant morphology by light needed in photosynthesis to produce carbohydrates. The process of photosynthesis that goes well will increase the vegetative growth of plants.

"Table 5" it can be seen that the growth that occurred at the N1 and N2 fertilization time intervals was relatively the same. The availability of sufficient water will accelerate plants to absorb nutrients and distribute nutrients to plants that need them. This was following the statement [15] 
who stated that water in plants is a solvent for various organic compounds (nutrients) from the soil into the plant. It transports photosynthate from the source to maintains turgidity, including in cells and opens stomata. Also, it is a primary component of protoplasm as well as a temperature regulator for plants. If the availability of groundwater lacks plants, air as the raw material for photosynthesis, the transportation of nutrients to the leaves will be hampered so that it will impact the resulting production.

The highest average value for the number of branches of Clitoria ternatea by giving different doses of sheep feces compost was found in the P3 treatment (compost dose $3 \mathrm{~kg} / \mathrm{plot}$ or $30 \mathrm{t} / \mathrm{h}$ ), namely 26.43 branches. In addition to containing $17.22 \% \mathrm{C}$ and $1.67 \% \mathrm{~N}$, sheep fecal compost also included the nutrient $\mathrm{P} 2.18 \%=21,800 \mathrm{ppm}$, which functions as a raw material for the formation of several proteins. It also helps the photosynthesis process so that plant parts such as stems, leaves, and branches of plants were able to grow well.

\subsection{Number of tillers of Brachiaria ruziziensis}

Table 6. Number of Brachiaria ruziziensistillers by giving sheep feces compost with different fertilization doses and intervals

\begin{tabular}{cccccc}
\hline Fertilization & \multicolumn{4}{c}{ Fertilizer Doses } & \multirow{2}{*}{ Average } \\
\cline { 2 - 4 } Interval & $\mathrm{P} 0$ & $\mathrm{P} 1$ & $\mathrm{P} 2$ & $\mathrm{P} 3$ & \\
\hline $\mathrm{N} 1$ & 29.33 & 38.58 & 51.00 & 38.67 & $39.40^{\mathrm{a}}$ \\
$\mathrm{N} 2$ & 29.92 & 41.42 & 48.08 & 65.42 & $46.21^{\mathrm{b}}$ \\
\hline Average & $29.63^{\mathrm{a}}$ & $40.00^{\mathrm{b}}$ & $49.54^{\mathrm{c}}$ & $52.04^{\mathrm{c}}$ & \\
\hline
\end{tabular}

Note: Different superscripts in the same column or row indicate significant differences $(\mathrm{P}<0.05)$

The analysis of variance showed that the time intervals for fertilization and the administration of different sheep feces compost had a significant effect $(\mathrm{P}<0.05)$ on the number of Brachiaria ruziziensis tillers, and there was no interaction between fertilization doses and intervals on Brachiaria ruziziensis tillers. This was because plants with good nutrients have a sound root system, so that the growth of their tillers also increases. This was under the statement [16], who stated that the formation of plant tillers would increase along with the growth and development of plants' addition of organic matter in the form of nutrients. In the vegetative growth phase, plants need nutrients to build meristem tissue, especially $\mathrm{C}$ and $\mathrm{N}$.

"Table 6" it can be seen that the highest average number of Brachiaria ruziziensis tillers was found in the $\mathrm{N} 2$ treatment (once every two weeks), which was 46.21 clumps. In N1 treatment (once every four weeks), the average number of Brachiaria ruziziensis tillers was lower, 39.40 clumps. This was due to the availability of sufficient nutrients and can be used quickly by plants to help growth and reproduction. [17] If enough space for plant growth and nutrients was available in the soil according to plant needs, more and more new individuals would be formed. 


\subsection{Fresh Mix Pasture Production}

Table 7. Fresh production of mixed pasture (g) by giving sheep feces compost with different fertilization doses and intervals

\begin{tabular}{|c|c|c|c|c|c|}
\hline \multirow{2}{*}{$\begin{array}{l}\text { Fertilization } \\
\text { Interval }\end{array}$} & \multicolumn{4}{|c|}{ Fertilizer Doses } & \multirow[t]{2}{*}{ Average } \\
\hline & P0 & P1 & P2 & P3 & \\
\hline N1 & 1201.67 & 1411.67 & 1855.00 & 1541.67 & $1502.50^{\mathrm{tn}}$ \\
\hline $\mathrm{N} 2$ & 1201.67 & 1601.67 & 1720.00 & 2111.67 & $1658.75^{\text {tn }}$ \\
\hline Average & $1201.67^{\mathrm{a}}$ & $1506.67^{b}$ & $1787.50^{\mathrm{c}}$ & $1826.67^{\mathrm{c}}$ & \\
\hline
\end{tabular}

Note: Different superscripts on the same row or column show significant differences $(\mathrm{P}<0.05), \mathrm{tn}=$ not significant

The results of the analysis of variance showed that the time interval for fertilization had no significant effect $(\mathrm{P}>0.05)$ on the production of mixed pasture fresh ingredients between Brachiaria Ruziziensis + Clitoria Ternatea, while the difference in the dose of sheep feces compost had a significant effect $(\mathrm{P}<0.05)$ on the production of ingredients. Freshly produced, and there is no interaction between the dose and interval of fertilization on the new production of mixed pasture. This was due to external factors in temperature, humidity, and insufficient sunlight intensity due to the research's implementation during the rainy season. This was under the statement [18], who stated that the photosynthesis process would take place well if the sunlight falls on the plant surface through optimal chlorophyll and will be disturbed otherwise.

"Table 7" it can be seen that proper fertilization affects the availability of nutrients in the soil will but the process of plant growth is influenced by many factors, especially the optimization of the process of photosynthesis. This was under the statement [19] who stated that the production of a plant is the result of the photosynthesis process. The decrease in assimilation due to respiration and the translocation of carbohydrates into plant products. Therefore, the increase in production is directly proportional to the rise in growth and photosynthetic yield.

Rated highest average production of fresh material with a dose of compost feces different found in treatment P3 (dose compost $3 \mathrm{~kg} / \mathrm{plot}$ or $30 \mathrm{t} / \mathrm{h}$ ) that is equal to $1826.67 \mathrm{~g} /$ plot differs from the research results [20] with results new production of Brachiaria Ruziziensis at 60 days cutting interval was $3696.470 \mathrm{~g} / \mathrm{plot}$. Inappropriate production results or a factor in the decline in new products can occur because this study uses a mixed cropping system that allows competition for plant nutrients. This was under the statement [21] also stated that planting distances that are too close would result in competition between plants for nutrients, sunlight, and water to spur plants to grow and allow maximum plant growth and development. 


\subsection{Percentage of Mixed Pasture Dry Materials}

Table 8. Production of mixed pasture dry matter (\%) by giving sheep feces compost with different fertilization doses and intervals

\begin{tabular}{cccccc}
\hline Fertilization & \multicolumn{4}{c}{ Fertilizer Doses } & \multirow{2}{*}{ Average } \\
\cline { 2 - 5 } Interval & $\mathrm{P} 0$ & $\mathrm{P} 1$ & $\mathrm{P} 2$ & $\mathrm{P} 3$ & \\
\hline $\mathrm{N} 1$ & 15.91 & 15.40 & 15.63 & 15.39 & $15.58^{\mathrm{tn}}$ \\
$\mathrm{N} 2$ & 13.95 & $12.99^{\mathrm{tn}}$ & 15.24 & 14.20 & $14.09^{\mathrm{tn}}$ \\
\hline Average & $14.93^{\mathrm{tn}}$ & $14.19^{\mathrm{tn}}$ & $15.43^{\mathrm{tn}}$ & $14,80^{\mathrm{tn}}$ & \\
\hline
\end{tabular}

Description: tn (not real)

The results of the analysis of variance showed that the time interval for fertilization and the dose of sheep feces compost had no significant effect $(\mathrm{P}>0.05)$ on the dry matter content of the mixed pasture between Brachiaria Ruziziensis + Clitoria Ternatea. There was no interaction between the doses and the interval of fertilization on the dry matter production of mixed pasture. [22] Pasture varieties respond differently to different environmental conditions, and plant growth and production are also influenced by plant genetic factors or themselves.

"Table 8" it can be seen that there is no significant effect between the two treatments. This was because the percentage of dry matter of feed material is influenced by the percentage of the levels of water content and cutting age. In this study, the mixed pasture harvesting process was carried out uniformly so that there was no significant difference between the dry matter content of each treatment. This was following the statement [23], who stated that the older the plant is cut, the higher the DM production. The highest average value of the percentage of dry matter with different doses of sheep feces compost was found in treatment P2 (compost dose $2 \mathrm{~kg} / \mathrm{plot}$ or $20 \mathrm{t} / \mathrm{h}$ ) which was $15.43 \% \mathrm{DM}$. If converted to fresh ingredients $1787.50 \mathrm{~g}$ x total of 10.000 $\mathrm{m} 2(1 \mathrm{ha})=17.875$ million $\mathrm{g} / \mathrm{ha}: 1000.000=17.88 \mathrm{t} / \mathrm{h} \times(365: 60)=108.77 \mathrm{t} / \mathrm{h} /$ year, dry weight of forage in P2 treatment was $15.43 \%$ x $108.77 \mathrm{t} / \mathrm{h} /$ year $=16.78 \mathrm{t} / \mathrm{h} /$ year. This was different from the statement [6] that the dry matter content in Brachiaria ruziziensisis $20 \%$ with the production of Brachiaria ruziziensisreaching an average of $24 \mathrm{t}$ of dry matter/ha/year. A mixed cropping system allows competition for plant nutrients, resulting in reduced food reserves available in the soil.

\subsection{Percentage of Crude Protein Content}

Table 9. Percentage of mixed pastura crude protein (\%) by giving sheep feces compost with different fertilization doses and intervals

\begin{tabular}{|c|c|c|c|c|c|}
\hline \multirow{2}{*}{$\begin{array}{c}\text { Fertilization } \\
\text { Interval }\end{array}$} & \multicolumn{4}{|c|}{ Fertilizer Doses } & \multirow[t]{2}{*}{ Average } \\
\hline & P0 & P1 & P2 & P3 & \\
\hline N1 & 7.05 & 7.34 & 7.95 & 9.09 & $7.86^{\mathrm{a}}$ \\
\hline $\mathrm{N} 2$ & 7.36 & 8.40 & 9.26 & 9,56 & $8.64^{b}$ \\
\hline Average & $7,20^{\mathrm{a}}$ & $7.87^{\mathrm{b}}$ & $8.60^{c}$ & $9.33^{\mathrm{d}}$ & \\
\hline
\end{tabular}

Note: Different superscripts in the same column and row show a significant effect $(\mathrm{P}<0.05)$

The results of the analysis of variance showed that the time interval for fertilizing and giving different doses of sheep feces compost had a significant effect $(\mathrm{P}<0.05)$ on the percentage of crude protein content in the mixed pasture between Brachiaria Ruziziensis + Clitoria Ternatea and there 
was an interaction between the dose and the interval of fertilization on the percentage of protein. Rough pasture mix. The sheep fecal compost given contains essential nutrients needed by plants, especially $\mathrm{N}$ nutrients, which were required by plants throughout their life cycle to grow and develop. This was following the statement [24], who stated that organic fertilizers could improve soil structure, increase soil absorption material for water, increase living conditions in the soil, and as a source of food substances for plants.

"Table 9" it can be seen that the highest mean percentage of crude protein content is in the N2 treatment (once every two weeks), which is $8.64 \%$, while in N1 treatment (once four weeks), the average percentage of crude protein was lower, namely $7.86 \%$. This was because the right time interval for fertilization will have an incredible impact on the availability of sufficient $\mathrm{N}$ for plants to help improve their quality. This was per the statement [25] who stated that $\mathrm{N}$ helps the photosynthesis process by producing chlorophyll that plants absorb. Besides that, it also functions for the protein formation process. The highest average value of the percentage of mixed pasture crude protein content with different doses of sheep feces compost was found in the P3 treatment (compost dose $3 \mathrm{~kg} / \mathrm{plot}$ or $30 \mathrm{t} / \mathrm{h}$ ), which was $9.33 \%$ different from the PK content of Brachiaria ruziziensis in the [26] that used pig feces compost which was only $8.63 \%$. This showed that the mixed cropping system between grass and legumes could increase the protein content in forage. This was by the statement [27] who stated that based on several research results on mixed cropping between grass and legumes, there is an increase in biomass production and high quality of forage.

\subsection{Percentage of Crude Fiber Content}

Table 10. Percentage of mixed pastura crude fiber (\%) with the provision of sheep feces compost with different fertilization doses and intervals

\begin{tabular}{cccccc}
\hline Fertilization & \multicolumn{4}{c}{ Fertilizer Doses } & \multirow{2}{*}{ Average } \\
\cline { 2 - 5 } Interval & $\mathrm{P} 0$ & $\mathrm{P} 1$ & $\mathrm{P} 2$ & $\mathrm{P} 3$ & \\
\hline $\mathrm{N} 1$ & 26.05 & 28.78 & 27.75 & 30.03 & $28.15^{\mathrm{a}}$ \\
$\mathrm{N} 2$ & 31.19 & 30.27 & 31.12 & 32.83 & $31.35^{\mathrm{b}}$ \\
\hline Average & $28.62^{\mathrm{a}}$ & $29.52^{\mathrm{b}}$ & $29.44^{\mathrm{b}}$ & $31.43^{\mathrm{c}}$ & \\
\hline
\end{tabular}

Note: Different superscripts in the same column and row show a significant effect $(\mathrm{P}<0.05)$

The results of the analysis of variance showed that the time interval for fertilizing and giving different doses of sheep feces compost had a significant effect $(\mathrm{P}<0.05)$ on the percentage of crude fiber content in the mixed pasture between Brachiaria Ruziziensis + Clitoria Ternatea and there was an interaction between the dose and the interval of fertilization on the percentage of fiber rough mixed pasture. This was because the $\mathrm{N}$ content in sheep fecal compost plays a role in growth and increase in crude plant fiber. The acceleration of growth results in high crude fiber in plants at harvest time. This was by the statement[28] who stated that Nitrogen $(\mathrm{N})$ is a plant nutrient for plant growth, which is generally indispensable for plants' formation and vegetative growth, such as leaves, stems, and roots. 
"Table 10" can be seen that the higher doses of the crude fiber increased and the average percentage of coarse fiber content highest in N2 treatment (once every two weeks) that is equal to $31.35 \%$. This was because at N2, plant growth is faster so that the crude fiber content is higher, while at $\mathrm{N} 1$, the development of new shoots is slower than $\mathrm{N} 2$ so that the crude fiber content is lower at harvest. This was by the statement [29], who stated that the nutrient content in the given soil could be properly absorbed by plants, resulting in rapid vegetative growth of plants, which made it easier for new shoots to grow so that their fiber content decreases is of high quality.

\section{Conclusion}

Provision of sheep manure compost with different fertilization doses and intervals can increase the productivity of mixed pasture. A dose of $3 \mathrm{~kg} / \mathrm{plot}$ or $30 \mathrm{t} / \mathrm{h}$ of feces compost gave the best results on plant height, number of leaves, number of tillers, number of branches, fresh production, dry matter, crude protein, and crude fiber of mixed pasta with. Fertilization interval of 2 weeks gave the best results on the number of leaves and the number of tillers of Brachiaria ruziziensis, and the percentage of crude protein and crude fiber content of mixed pasture.

\section{REFERENCES}

[1] Hawolambani, Y.U., H. P. Nastiti, Y. H. Manggol. 2015. Produksi Hijauan Makanan Ternak Dan Komposisi Botani Padang Penggembalaan Alam Pada Musim Hujan Di Kecamatan Amarasi Barat Kabupaten Kupang. Jurnal Nukleus Peternakan. Vol. 2, No. 1:59-65.

[2] Utami, P. 2008. Buku Pintar Tanaman Obat. PT. Agromedia Pustaka, Jakarta.

[3] Rajiman. 2020. Pengantar Pemupukan. Deepublish Publisher. Yogyakarta.

[4] Andayani dan L. Sarido. 2013. Uji Empat Jenis Pupuk Kandang Terhadap Pertumbuhan Dan Hasil Tanaman Cabai Keriting (Capsicum annum L.). 2013. Jurnal AGRIFOR Vol.XII No.1:22-29.

[5] Kosai, P., K. Sirisidthi, K. Jiraungkoorskul, and W. Jiraungkoorskul. 2015. Review on Ethnomedicinal uses of Memory Boosting Herb, Butterfly Pea, Clitoria ternatea. Journal of Natural Remedies Vol.15 No.2:71-76.

[6] Pusat Penelitian dan Pengembangan Peternakan. 2009. Loka Penelitian Kambing Potong Sei Putih. Galang, Deli Serdang.

[7] Faizal, R., S. Raden, dan Sigit S. 2017. Karakter Fisiologis Dan Produksi Padi Ratun Yang Di Aplikasi Synechococcus Sp. Dan Pupuk Organik. Skripsi. Universitas Jember. Jawa Timur.

[8] Sugih, O. 2005. 88 Variasi Adenium Agar Rajin Berbunga. Penebar Swadaya. Jakarta.

[9] Musnamar, 2003. Pupuk Organik (Cair dan Padat, Pembuatan, Aplikasi). Penebar Swadaya. Jakarta.

[10] Rosmarkam, A. dan N. W. Yuwono. 2002.Ilmu kesuburan tanah. Yogyakarta. 
[11] Purwanto, J., A. Asngad, T. Suryani. 2012. Pengaruh Media Tanam Arang Sekam dan Batang Pakis Terhadap Pertumbuhan Cabai Merah Keriting (Capsicum annum L.) Ditinjau Dari Intensitas Penyiraman Air Kelapa. Prosiding. Seminar Nasional IX Pendidikan Biologi FKIP UNS. 07 Juli 2012. Universitas Sebelas Maret. pp.642-647.

[12] Sutedjo, M. M. 2002. Pupuk dan Cara Pemupukan. Rineka Cipta, Jakarta.

[13] Munawar, A. 2011. Kesuburan Tanah dan Nutrisi Pemupukan. IPB Press. Bogor.

[14] Damanik. M. H. 2020. Pengaruh Pupuk Organik Cair Dari Limbah Pasar dan Air Cucian Beras Terhadap Pertumbuhan Serta Hasil Panen Tanaman Okra Merah (Abelmoschus esculentus). Skripsi. Universitas Sanata Dharma. Yogyakarta.

[15] Maryani, A. T. 2012. Pengaruh Volume Pemberian Air Terhadap Pertumbuhan Bibit Kelapa Sawit Di Pembibitan Utama. Skripsi. Universitas Jambi. Jambi.

[16] Purbajanti, E. D. 2013. Rumput dan Legum. Penerbit Graha Ilmu. Yogyakarta.

[17] Muhakka, A. Napoleon, H. Isti'adah. 2013. Pengaruh Pemberian Asap Cair Terhadap Pertumbuhan Rumput Raja (Pennisetum purpureophoides). Pastura Vol.3 No.1:30-34

[18] Sawen, D. 2012. Pertumbuhan Rumput Gajah (Pennisetum purpureum) Dan Benggala (Panicum maximum) Akibat Perbedaan Intensitas Cahaya. Agrinimal Vol.2 No. 1:17-20.

[19] Jumin, H. B. 2008. Dasar-dasar Agronomi. PT. RajaGrafindo Persada. Jakarta.

[20] Nababan, S. 2016. Pemberian Kompos Ternak Babi Dengan Dosis Yang Berbeda Terhadap Produktivitas Hijauan Ruzi (Brachiaria ruziziensis) Dengan Interval Pemotongan Yang Berbeda. Skripsi. Universitas Sumatera Utara. Medan.

[21] Utomo, W., M. Astiningrum. \& Y.E. Susilowati. 2017. Pengaruh mikoriza dan jarak tanam terhadap hasil tanaman jagung manis (Zea mays Var. Saccharata Sturt). Jurnal Ilmu Pertanian Tropika dan Subtropika Vol.2 No.1:28-33.

[22] Wijaya, A.K., Muhtarudin., Liman., C.Antika, dan D. Febriana. 2018. Produktivitas Hijauan Yang Ditanam Pada Naungan Pohon Kelapa Sawit Dengan Tanaman Campuran. Jurnal Ilmiah Peternakan Terpadu Vol.6 No.3:155-162.

[23] Seseray, D.Y., E.W. Saragih, dan Y. Katiop. 2012. Pertumbuhan Dan Produksi Rumput Gajah (Pennisetum Purpureum) Pada Interval Defoliasi Yang Berbeda. Jurnal Ilmu Peternakan Vol.7 No.1:31-36.

[24] Lingga, P. Marsono. 2008. Petunjuk Penggunaan Pupuk. Rajawali Press. Jakarta.

[25] Purba, M. A. 2016. Pemanfaatan Sluri Gas Bio Dengan Input Feses Kambing Dan Biji Durian Terhadap Kualitas Nutrisi Pastura Campuran. Skripsi. Universitas Sumatera Utara. Medan.

[26] Artha, I. R. 2016. Pengaruh Pemberian Dosis Kompos Ternak Babi Dan Interval Pemotongan Terhadap Kualitas Hijauan Ruzi (Brachiaria Ruziziensis). Skripsi. Universitas Sumatera Utara. Medan.

[27] Hasan, S., Budiman, R. Ilham dan Sudarsono. 2015. Peningkatan Produktivitas Padang Penggembalaan Kritis melalui Pertanaman Campuran antara Rumput dan Legum sebagai 
Sumber Biological NitrogenFixation (BNF) di Kabupaten Sidenreng Rappang. Prosiding. Seminar Nasional Peternakan Berkelanjutan 7. 11 November 2015. Sumedang. pp.257-263 [28] Prasetyo, A. 2014. Pengolahan Tanah Bagi Tanaman. Penebar Swadaya. Jakarta.

[29] Syaroh, D. M. 2015. Pemanfaatan Sluri Gas Bio Campuran Kotoran Kambing Dan Ampas Tebu Terhadap Kambing Dan Ampas Tebu Terhadap Produktivitas Pastura campuran. Skripsi. Universitas Sumatera Utara. Medan 